\title{
KELAYAKAN INDUSTRI KOPI DI PROVINSI KALIMANTAN BARAT
}

\author{
The Feasibility Of Coffee Industries In West Kalimantan Province
}

\author{
Rudy Setyo Utomo \\ Pusat Penelitian Pemerintahan Umum dan Kependudukan \\ Kantor Penelitian dan Pengembangan Provinsi Kalimantan Barat \\ Jl. Adi Sucipto No. 50, Telp+62561 572898 \\ E-mail: rudystyo@gmail.com \\ Dikirim: 13 Juli 2014; direvisi: 20 Juli 2014; disetujui: 2 September 2014
}

\begin{abstract}
Abstrak
Tujuan penelitian ini adalah untuk mengetahui kelayakan industri kopi rakyat sebagai penghasil produk komersial di Kalimantan Barat. Penelitian dilakukan secara deskriptif dan observasi untuk mengetahui potensi bahan baku, potensi pasar dan pemasaran, ketersediaan teknologi, dan analisis kelayakan finansial pendirian pabrik. Hasil-hasil penelitian menunjukkan bahwa ketersediaan bahan baku berupa hasil panen kopi menurun setiap tahun dan ketersediaannya pada setiap masyarakat kecil, dan tidak menarik bagi petani untuk budidaya komersial, kalah bersaing dengan keberadaan tanaman karet, kelapa sawit, atau tanaman hortikultura atau perkebunan lain, sehingga masyarakat enggan menanam kopi kembali. Walaupun, pemasaran kopi tersedia pada pasar domestik, pasar nasional, dan luar negeri, akan tetapi mutu kopi yang berkaitan dengan keunggulan rasa, aroma, dan indikasi geografi merupakan keunggulan tersendiri, yang belum tampak untuk hasil kopi asal Kalimantan Barat. Teknologi pengolahan kopi menunjukkan adanya kesiapan teknologi untuk aplikasi, seperti teknologi untuk menghasilkan produk kopi primer dan kopi sekunder. Saran yang dapat diberikan adalah budidaya kopi dan produk kopi luwak liar (Paradoxurus hermaphrodites) dari Kabupaten Sambas perlu diperhatikan dan dibina intensif oleh Pemerintah Daerah setempat, agar memiliki peluang komersialisasi kompetitif. Sebaiknya Pemerintah Daerah membina kembali teknik budidaya dan manajemen usaha tani kopi. Kata kunci: produk komersial, kelayakan industri, bahan baku, teknologi.
\end{abstract}

\begin{abstract}
The purpose of this study was to determine the feasibility of the coffee industry folk as a commercial producer in West Kalimantan. Research conducted descriptive and observation to determine the potential of raw materials, market potential and marketing, availability of technology, and financial feasibility analyzes plant establishment. The results of the study showed that the availability of raw materials such as coffee yields declined every year and its availability on every small community, and not attractive to farmers for commercial cultivation, where plants can not compete with rubber, palm oil, or other horticultural crops or plantation, so people are reluctant to plant coffee again. Although, the marketing of coffee available on the domestic market, national market and abroad, but the quality of the coffee that is associated with superior taste, aroma, and geography indications is its own advantages, which have not seemed to result from West Kalimantan coffee. Coffee processing technology indicates the readiness of technology for applications, such as the technology to produce coffee of primary and secondary copy. Advice can be given is the cultivation of coffee and wild civet coffee products (Paradoxurus hermaphrodites) from Sambas district and fostered intensive note by the local government, in order to have a competitive commercialization opportunities. Local Government should reestablish cultivation techniques and management of coffee farming.
\end{abstract}

Keywords: commercial product, the feasibility of industrial, raw materials, technology.

\section{PENDAHULUAN}

Kopi (Coffea sp.) merupakan salah satu produk perkebunan di Kalimantan Barat. Lokasi perkebunan kopi banyak berada di Kabupaten Kubu Raya, Kabupaten Sambas, Kabupaten Ketapang, Kabupaten Landak, dan hampir pada semua kabupaten dijumpai ada produk kopi yang diusahakan oleh petani, seperti diperlihatkan pada Tabel 1. Tanaman kopi banyak ditanam pada pekarangan dan atau di halaman rumah.

Produk umum kopi yang banyak beredar di masyarakat antara lain kopi bubuk. Ada produk kopi yang menarik seperti kopi pancong, kopi saring, kopi instan, dan kopi luwak, banyak diminati oleh penggemar kopi di Pontianak dan di setiap kabupaten di Kalimantan Barat. Kopi bubuk juga diperdagangkan di pasar-pasar Pontianak walaupun tidak terlalu luas. Akan tetapi kopi ini bukan merupakan salah satu komoditi unggulan di Kalimantan Barat (SK Gubernur Provinsi Kalimantan Barat Nomor 505 tahun 2002).

Menurut Azhary (1986) dalam Asri (2010) terdapat beberapa alasan kuat yang mendasari pentingnya keberadaan industri kecil dan rumah tangga dalam perekonomian Indonesia. Alasan-alasan itu antara lain: (1) Sebagian besar lokasi industri kecil dan rumah tangga berlokasi di daerah pedesaan, sehingga apabila dikaitkan dengan kenyataan bahwa lahan pertanian semakin berkurang, maka industri kecil dan rumah tangga di pedesaan dapat menyerap 
Tabel 1. Luas, produksi, dan produktivitas kopi pada masing-masing kabupaten dan kota di Kalimantan Barat, tahun 2012

\begin{tabular}{clrrr}
\hline No & Kabupaten & Luas (Ha) & Produksi (Ton) & Produktivitas (Ton/Ha) \\
\hline 1 & Kab. Sambas & 2.149 & 558 & 0.321 \\
2 & Kab Bengkayang & 436 & 125 & 0.263 \\
3 & Kab Landak & 1.148 & 509 & 0.420 \\
4 & Kab Pontianak & 640 & 228 & 0.475 \\
5 & Kab Sanggau & 207 & 85 & 0.385 \\
6 & Kab Ketapang & 1.308 & 509 & 0.454 \\
7 & Kab Sintang & 354 & 102 & 0.277 \\
8 & Kab Kapuas Hulu & 46 & 16 & 0.273 \\
9 & Kab Sekadau & 10 & 1 & 0.100 \\
10 & Kab Melawi & 61 & 19 & 0.311 \\
11 & Kab Kayong Utara & 657 & 492 & 0.375 \\
12 & Kab Kubu Raya & 5.369 & 1.190 & 0.200 \\
13 & Kota Pontianak & 0 & 0 & 0.000 \\
14 & Kota Singkawang & 22 & 15 & 0.864 \\
& Jumlah & 12.407 & 3.849 & 0.373 \\
\hline
\end{tabular}

Sumber: BPS Kalbar, 2013.

tenaga kerja di daerah pedesaan, (2) Kegiatan industri kecil dan rumah tangga menggunakan bahan baku dari sumber-sumber di lingkungan terdekat yang menyebabkan biaya produksi rendah, (3) Dengan tingkat pendapatan masyarakat relatif rendah serta harga produk industri kecil dan rumah tangga murah akan memberikan peluang agar tetap bisa bertahan, dan (4) Tetap ada permintaan terhadap produk yang tidak diproduksi secara besar-besaran.

Produksi kopi di Kalbar ini telah ada di masyarakat secara turun temurun tetapi belum ada kegiatan besar yang mengembangkan produk kopi baik dari Pemerintah Daerah maupun dari pihak swasta. Selama ini, kopi masih dikelola secara tradisional oleh masyarakat.

Yang menjadi masalah dalam penelitian ini adalah apakah produk olahan kopi dapat berkembang secara komersial di Kalimantan Barat, hingga penelitian ini dilakukan. Tujuan penelitian ini adalah untuk mengetahui kelayakan industri kopi rakyat sebagai penghasil produk komersial di Kalimantan Barat.

\section{METODE PENELITIAN}

Penelitian dilaksanakan pada tahun 2013, dengan lokasi berada di Kabupaten Sambas dan Kabupaten Pontianak, Provinsi Kalimantan Barat. Data yang diperlukan adalah data primer dan data sekunder. Data primer didapat dari pengusaha kopi dan petani pemiliki kebun kopi di dua kabupaten. Data sekunder diperoleh dari institusi pemerintah daerah yang ada pada kedua kabupaten itu.

Analisis kelayakan industri kopi dilakukan mengikuti diagram seperti pada Gambar 1. Beberapa aspek yang berkaitan dengan pendirian pabrik kopi dilakukan terhadap ketersediaan dan keberlangsungan bahan baku buah kopi, pasar dan pemasaran, ketersediaan teknologi, dan analisis finansial. Jika pendirian pabrik kopi dianggap layak maka analisis dilanjutkan pada aspek yuridis yang berhubungan dengan organisasi perusahaan dan manajemen, dan analisis lingkungan dan legalitas.

Penentuan ketersediaan bahan baku dilakukan dengan identifikasi potensi produk primer kopi yang ada di Kalimantan Barat melalui data sekunder dan data primer. Data sekunder berasal dari dokumen pemerintah dan data primer dari informasi yang diberikan oleh patani kopi.

Mendiskripsikan peralatan-peralatan yang dipilih dengan sesuai dengan kriteria ketersediaan alat-alat, dapat dibuat dan dioperasikan dengan mempertimbangkan spesifikasi peralatan yang mampu menghasilkan produk optimum sesuai permintaan pasar.

Analisis jenis produk pengolahan kopi yang bernilai komersial dilakukan dengan menginventarisir produk dan proses-proses pengolahan yang telah dilakukan masyarakat di Kabupaten Pontianak dan Kabupaten Sambas dalam usaha rumah tangga, kecil, menengah dan besar, dan juga produk olahan kopi yang telah berkembang secara nasional dan internasional.

Kelayakan pendirian pabrik kopi berhubungan dengan (1) permintaan jenis produk oleh pasar lokal, nasional, atau internasional, (2) skala proses pengolahan dan produksi berkaitan dengan ketersediaan bahan baku, ketersediaan bahan baku erat kaitannya dengan persaingan usaha tani dengan komoditas lain di Kalbar, terutama usaha tani kelapa sawit dan karet. 


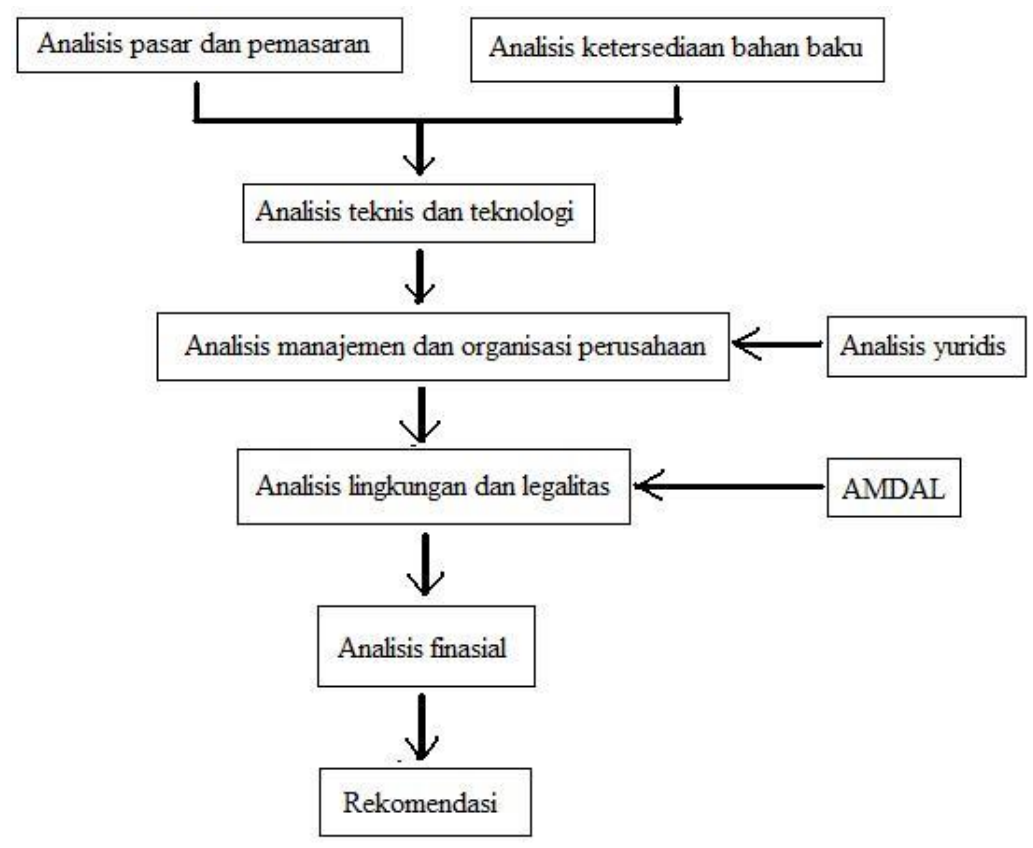

Gambar 1. Kerangka pemikiran dalam penelitian, kelayakan industry kopi di Kalimantan Barat

\section{HASIL DAN PEMBAHASAN}

\section{Ketersediaan Bahan Baku}

Beberapa jenis kopi yang berproduksi di Kalimantan Barat, diduga terbanyak adalah kopi robusta dan liberika. Robusta banyak tumbuh dan berkembang di daerah kering serta liberika banyak berkembang di sekitar rawa. Kualitas buah kopi robusta lebih rendah daripada kopi arabika, tetapi lebih tinggi daripada kopi liberika.

Di dua kabupaten, yaitu Kabupaten Sambas dan Kabupten Pontianak, berturut-turut produktivitas kopi rata-rata $321 \mathrm{~kg} / \mathrm{ha} / \mathrm{th}$ dan $475 \mathrm{~kg} / \mathrm{ha} / \mathrm{th}$ (Tabel 1). Produktivitas ini masih jauh di bawah produktivitas rata-rata nasional. Padahal budidaya kopi oleh masyarakat sudah dikelola sejak puluhan tahun yang lalu.

Dari tabel tersebut terlihat bahwa kopi tumbuh pada hampir semua kabupaten, kecuali Kota Pontianak. Sebenarnya, penghasil kopi dominan berasal dari Kabupaten Kubu Raya, Kabupaten Sambas, Kabupaten Ketapang, dan Kabupaten Landak. Sedang kopi di kabupaten lainnya, luasnya kurang dari 1.000 Ha. Masyarakat umumnya masih mengelola perkebunan kopi secara tradisional, belum mendapatkan pembinaan dan fasilitas yang berarti dari Pemerintah Daerah, karena tidak menjadi komoditas unggulan perkebunan.

Perkembangan kopi dibanding kelapa sawit terlihat pada grafik di Gambar 1, tren komoditas kopi menurun dengan konstanta penurunan $-52,4$ berlainan dengan tren kelapa sawit meningkat dengan kontanta kenaikan 4.058 dan karet juga meningkat dengan konstanta 438,4 (lihat Gambar 1). Atas dasar grafik itu, jika kondisi ini dibiarkan tanpa pembinaan kemungkinan 17 tahun lagi produksi kopi akan hilang di tingkat petani.
Demikian pula, di Kabupaten Pontianak juga terjadi tren penurunan luas perkebunan kopi dengan konstanta penurunan $-41,6$, sedang untuk tanaman perkebunan kelapa sawit, karet dan kelapa dalam meningkat (lihat Gambar 2). Yang meningkat tajam adalah luas kelapa sawit. Diperkirakan perkebunan kopi di Kabupaten Pontianak pada 9 tahun yang akan datang akan hilang dari Kabupaten Pontianak, atas dasar tren penurunan yang terjadi, jika tidak ada pembinaan dari Pemerintah Daerah.

Kopi Arabika tumbuh dan berproduksi dengan baik pada ketinggian $800 \mathrm{~m}$ dpl (dari permukaan air laut) hingga $2.000 \mathrm{~m} \mathrm{dpl} \mathrm{dengan} \mathrm{elevasi} \mathrm{optimal}$ antara $1.000 \mathrm{sd} 1.500 \mathrm{mdpl}$ dengan suhu rata-rata tahunan antara $17^{\circ} \mathrm{C}$ sd $21^{\circ} \mathrm{C}$. Sedang kopi Robusta dapat ditanam pada ketinggian dari 0 mdpl sd 1.000 mdpl dengan ketinggian optimal pada $400 \mathrm{mdpl}$ sd $800 \mathrm{mdpl}$, dan suhu tahunan sekitar $21^{\circ} \mathrm{C}$ sd $24^{\circ} \mathrm{C}$ (Karo, 2009). Melihat syarat tumbuh ini, kopi sebenarnya kurang sesuai berkembang di Kalimantan Barat.

Suatu industri dapat tumbuh dan berkembang bila didukung oleh beberapa karakteristik, yaitu (1) Status Usaha, (2) Tenaga Kerja, (3) Modal, dan (4) Bahan Baku. Bahan baku adalah bahan yang digunakan sebagai bahan pokok dalam produksi untuk menghasilkan barang setengah jadi maupun barang jadi (Soraya, 2011). Biasanya industri tumbuh dan berkembang karena berbagai alasan antara lain adanya keterkaitan bahan baku setempat dan faktor keahlian yang turun temurun (Soraya, 2011).

Bahan baku yang digunakan dalam kegiatan produksi perlu mempertimbangkan hal-hal yang menyangkut: a) Jumlah kebutuhan bahan baku selama satu periode, b) Kelayakan harga bahan baku, c) Kontinuitas (kelangsungan, kesinambungan) persediaan barang, d) Kualitas bahan baku, dan e) 


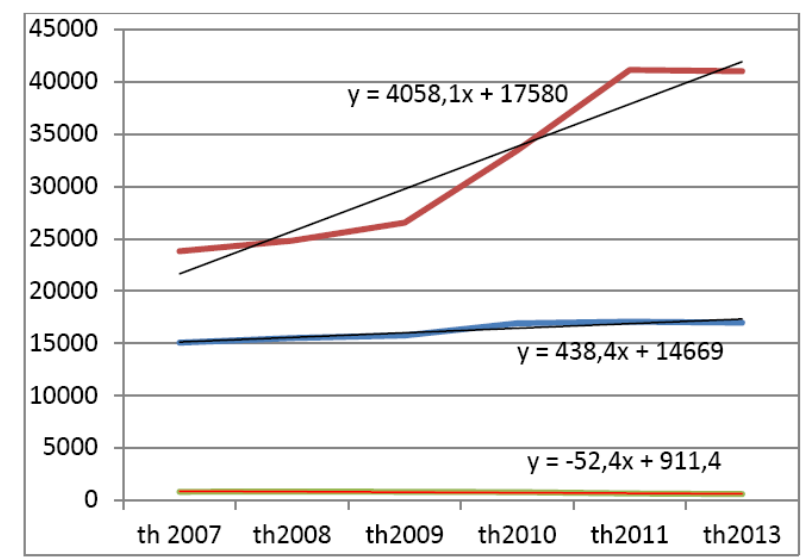

Sumber: Grafik diolah dari data BPS Sambas tahun 2012 dan tahun 2013

Gambar 2. Tren produksi kopi disbanding dengan kelapa sawit dan karet
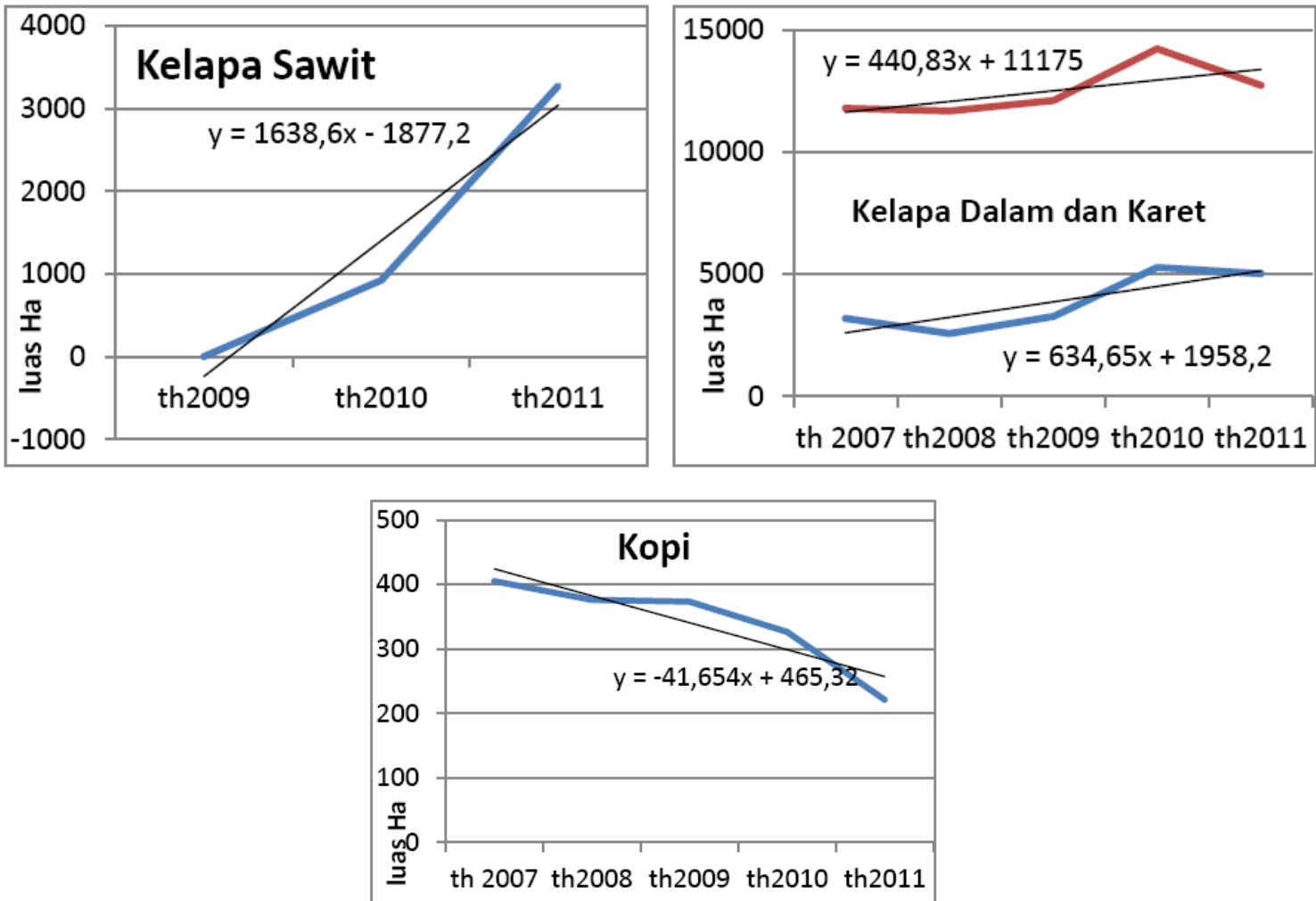

Sumber: Grafik diolah dari data BPS Kabupaten Pontianak (2012)

Gambar3. Tren perkembangan luas lahan kelapa sawit, kelapa dalam, karet, dan kopi di Kabupaten Pontianak

Biaya pengangkutan. Dengan tidak adanya bahan baku pada industri tersebut maka proses produksi tidak akan berjalan, dan proses produksi akan berjalan kembali ketika bahan baku sudah ada atau dapat dikatakan proses produksi dipengaruhi bahan baku (Soraya, 2011).

\section{Pasar dan Pemasaran}

Harga kopi biji kecil lebih mahal dari pada kopi biji besar, kopi biji kecil lebih disukai masyarakat daripada yang besar. Yang kecil adalah kopi robusta dan yang besar adalah liberika. Harga kopi beras di Kabupaten Sambas lebih mahal daripada harga kopi di
Kabupaten Pontianak. Harga kopi biji/beras di Sambas antara Rp. 22.000 sd Rp. 26.000/kg. Sedang harga kopi biji / beras di Kabupaten Pontianak antara Rp. $20.000 \mathrm{sd}$ Rp 22.000/kg.

Kopi dibudidaya masyarakat hanya untuk konsumsi keluarga sendiri, minat untuk budidaya komersial menurun. Kopi luwak juga ditemukan di Kabupaten Sambas, tidak dikenal masyarakat sebagai kopi mahal, sehingga masyarakat tidak terlalu mengkomersialisasi keberadaan kopi luwak. Kopi luwak di Kabupaten Sambas tidak diperdagangkan secara khusus dan tidak ditangani secara khusus walaupun dikenal sebagai kopi yang baik. 
Perusahaan kopi yang ada merupakan usaha turun-temurun dari orang tua kepada anak dan kepada cucunya. Walaupun industri kopi ini menurut pengakuan pemiliknya mengalami penurunan akan tetapi industri ini tetap bertahan dengan kapasitas penualan makin menurun.

Produksi kopi di Kabupaten Pontianak semakin menurun, dan menunjukkan bahwa petani di kecamatan penghasil kopi tertinggi di kabupaten ini menurun minatnya terhadap penanaman dan perawatan kopi, karena dinilai tidak menguntungkan jika dibanding dengan tanaman kelapa, pisang, karet dan kelapa sawit. Penurunan produksi kopi di petani berpengaruh terhadap keberadaan pedagang kopi lokal dan keberadaan industri kopi daerah yang masih berskala home industry.

Permasalahan budidaya kopi di tingkat petani adalah harga jual tidak sesuai dengan biaya yang dikeluarkan untuk mengolah kopi menjadi kopi beras atau bubuk, atau harga jual kopi terlalu rendah sehingga tidak menarik untuk diproduksi secara komersial.

\section{Teknologi}

Proses pengolahan kopi yang dilakukan masyarakat di Kabupaten Sambas masih tradisional. Setelah buah dikupas, dilakukan fermentasi, dan dijemur. Masyarakat umumnya mengenal proses fermentasi untuk menghilangkan lendir setelah pengupasan.

Untuk menghilangkan kulit tanduk biasa dilakukan dengan sangrai dilanjutkan menumbuk biji kopi hingga semua kulit tanduk pecah. Sangrai adalah proses pemanasan biji kopi agar biji kopi mengeluarkan aroma dan mudah dipecahkan kulit dan dibuang kulit tanduknya. Untuk sangrai memerlukan waktu minimal 1 jam, memerlukan energi panas yang diperoleh dari bahan bakar biomassa, yaitu pembakaran kayu. Sangrai, dilakukan secara manual dengan menempatkan biji kopi dalam silinder logam bertangkai. Selama pemanasan silinder diputar-putar agar panas dapat tersebar merata mengenai kopi.

Ada upaya dari petani untuk rekayasan peralatan dan mesin penggiling kopi atau pemecah kulit tanduk, karena pekerjaan pemecahan kulit tanduk memakan waktu jika dilakukan secara manual. Jika pemecahan kulit tanduk ini diupahkan, akan rugi.

Dari beberapa sampel penelitian di Kabupaten Sambas diperoleh data ada pabrik yang hanya mengerjakan jasa sangrai, menerima kopi beras dan mengembalikan dalam bentuk kopi biji yang sudah di sangrai. Pihak pengusaha hanya menerima upah jasa sangrai. Kapasitas sangrai sekitar 800 kg/hari. Menggunakan bahan bakar sebagai energi panas dari kayu yang dibakar. Permasalahan umum dari pabrik ini adalah pabrik kekurangan pasokan bahan baku biji kopi. Suplai masyarakat akan biji kopi menurun dan bahkan tidak dilakukan lagi oleh masyarakat.

Di Kabupaten Sambas juga diketahui bahwa petani enggan mengurus tanaman kopinya karena tidak menguntungkan baginya. Nilai produksi kopi kalah bersaing dengan tanaman karet dan kelapa sawit. Bahkan petani pemilik kebun kopi sering mengupahkan panen kepada orang lain, dan hanya memperoleh pendapatan Rp. 600/kg dari setiap kg biji kopi yang didapat. Pada saat tertentu, buah kopi masak yang jatuh ke tanah dibiarkan terhampar di atas tanah, tidak dipungut karena alasan ekonomi.

Pabrik kopi yang sudah beroperasi selama 40 tahun, merupakan warisan orang tuanya. Permasalahan umum yang dijumpai adalah ketersediaan bahan baku. Bahan baku kebanyakan bukan berasal dari produk kopi lokal atau petani di Kabupaten Sambas melainkan berasal dari toko di Kota Singkawang. Toko di Kota Singkawang menerima kopi biji atau beras dari luar provinsi. Beberapa sumber menyebutkan berasal dari Provinsi Lampung. Sebelumnya biji kopi dipasok dari Kecamatan Galing, Kabupaten Sambas, akan tetapi sekarang tidak lagi. Keluhan yang umum ditemukan adalah tidak ada perkembangan dan kemajuan kapasitas penjualan maupun peningkatan keuntungan kopi. Asal kopi yang dijual di Singkawang banyak berasal dari Lampung, Sumatera Selatan, dan Jakarta. Walaupun kopi asal kedua daerah ini dinilai mutunya kurang baik, karena dicampur antara kopi masak dengan kopi muda (belum masak). Masalah berikutnya adalah menurunnya tingkat penjualan dengan alasan kalah berkompetisi dengan produk kopi instan yang berasal dari produk luar daerah.

Kebanyakan industri kopi yang ada di Kabupaten Sambas masih berskala home industry dan kecil belum menunjukkan adanya skala yang lebih besar. Peralatan dan mesin yang digunakan masih berskala home industry.

Produksi kopi beras atau biji kopi di Kabupaten Sambas banyak dihasilkan dari petani. Petani disamping menanam pohon kopi, memetik dan selanjutnya memperlakukan hasil panen dengan mengupas, menjemur, dan menggiling untuk memperoleh kopi beras.

Beberapa kesulitan petani adalah panen karena pohon terlalu tinggi sehingga sulit dipetik. Biasanya pemetik adalah perempuan. JIka buah tidak mampu dipetik, maka buah dibiarkan masak dipohon dan menunggu jatuh ke permukaan tanah untuk dipungut.

Industri kopi di Kabupaten Pontianak umumnya berskala home industry dan industri kecil sehingga beberapa diantaranya tidak wajib membuat ijin usaha. Hanya satu industri yang berkategori menengah atau besar, yaitu PD Utama Jaya yang berada di Desa Wajok, Siantan, Kabupaten Pontianak. Industri ini banyak memperoleh bahan baku dari Lampung, bukan dari Kabupaten Pontianak (Kalimantan Barat). Jenis kopi di Kabupaten Pontianak adalah Robusta.

Proses pengolahan buah kopi yang dilakukan di Kabupaten Pontianak antara lain, setelah buah kopi dipetik dari pohon, dikupas dengan menggunakan mesin sederhana buatan sendiri, lalu dijemur selama 2 hari atau buah kopi langsung dijemur bersama-sama 
dengan kulit. Penjemuran buah kopi bersama-sama dengan kulitnya biasanya dilakukan selam 4 hingga 5 hari, lalu ditumbuk untuk menghilangkan kulit.

Pengupasan juga biasa dilakukan dengan mesin dengan upah jasa mesin Rp 300/kg sd Rp 500/kg buah kopi. Setelah dikupas, biji lalu dijemur untuk memudahkan pelepasan kulit yang masih menempel pada biji. Penjemuran biasanya selama 2 hari. Setelah kopi dijemur ditumbuk dengan menggunakan lesung. Setelah itu kopi dibersihkan dari kotoran-kotoran yang melekat dengan ditampi dan kemudian dijemur kembali untuk mendapatkan kopi beras kering atau kopi biji. Kopi beras atau kopi biji ini biasa langsung dijual ke toko. Menurut Cahyana (2008), proses produksi ini adalah proses semi mekanik, yang sebgian dikerjakan dengan tangan, sehingga perlu mendapat perhatian dan perbaikan.

Permasalahan umum yang ditemukan dari pabrik kopi yang beroperasi di Kabupaten Pontianak antara lain adalah bahan baku tidak mampu diperoleh dari lokal melainkan lebih banyak didapatkan dari Kota Pontianak dari penyalur atau penjual kopi beras. Dinyatakan asal kopi beras tersebut berasal dari Kota Semarang dan dari Lampung.

Mutu kopi rendah banyak diakibatkan oleh bahan baku berasal dari biji kopi campuran antara biji tua dan biji muda, atau bahkan lebih banyak biji muda. Karena proses panen yang dilakukan petani diluar pengendalian pengusaha pengolahan kopi bubuk. Mutu kopi beras ini yang menjadi keluhan utama rendahnya mutu produk kopi bubuk di Kabupaten Pontianak.

Rendahnya mutu produk ini bersaing penuh dengan produk pabrik lain yang masuk ke Kabupaten Pontianak. Dapat diperkirakan kemungkinan produk kopi di Kabupaten Pontianak akan selalu mengalami penurunan. Ungkapan yang dinyatakan oleh pengusaha juga menyebutkan bahwa penjualan semakin sulit dan berkurang.

Permasalahan pengusaha pabrik kopi di Kabupaten Pontianak antara lain juga masih pada kesulitan bahan baku dan ketidakmampuan bersaing dengan produk kopi bubuk lain, sehingga loka pemasaran mengarah ke daerah hulu atau ke daerah pedalaman. Pelaksanaan proses produksi juga masih manual, tidak ada rencana untuk memperbaiki peralatan.

Produk kopi yang banyak beredar di pasar dikelompokkan ke dalam dua jenis, yaitu produk kopi primer yaitu berupa biji kopi dan produk kopi sekunder, berupa produk olahan dari biji kopi menjadi berbagai macam jenis konsumsi. Beberapa jenis peralatan dan mesin yang digunakan untuk mengolah kopi tersebut telah banyak diteliti dan selalu dikembangkan, beberapa diantaranya adalah: mesin pengupas kulit buah kopi (pulper) dengan beberapa spesifikasi kapasitas dan harga, antara lain berkapasitas $50 \mathrm{~kg} / \mathrm{jam}$ (manual), kapasitas 200 $\mathrm{kg} / \mathrm{jam}$ (degerakkan oleh motor bensin 5,5 PK), kapasitas 1 ton/jam digerakkan oleh motor bensin 5,5
PK, dan kapasitas 3 ton/jam digerakkan oleh motor diesel 16 PK (Mulato dkk., 2010).

Proses fermentasi umumnya dilakukan untuk pengolahan kopi Arabika dan tidak banyak dipraktekkan untuk pengolahan kopi Robusta terutama untuk kebun rakyat. Tujuan dari proses fermentasi adalah untuk menghilangkan lapisan lendir yang tersisa pada permukaan kulit tanduk biji kopi setelah proses pengupasan. Pada kopi Arabika, fermentasi bertujuan untuk mengurangi rasa pahit dan mendorong terbentuknya kesan "mild" pada cita rasa seduhannya. Umunya waktu fermentasi biji kopi untuk Arabika antara 12 hingga 36 jam dan untuk Robusta lebih pendek (Mulato dan Suharyanto, 2011).

Mesin pencuci (washer) telah diproduksi dengan beberapa spesifikasi, diantaranya kapsitas $100 \mathrm{~kg} / \mathrm{jam}$ yang digerakkan oleh motor bensin 5,5 PK, kapasitas $500 \mathrm{~kg} / \mathrm{jam}$ digerakkan oleh motor diesel 10 - $12 \mathrm{PK}$, dan kapasitas $1.000 \mathrm{~kg} / \mathrm{jam}$ digerakkan oleh motor diesel 20-22 PK atau motor listrik 16-20 PK, Pencucian digunakan untuk menghilangkan sisa lendir yang masih menempel pada kulit dari hasil fermentasi. Ada dua tipe mesin pencuci yaitu tipe batch dan tipe kontinyu (Puslit Kopi dan Kakao, 2013).

Proses pengeringan bertujuan untuk mengurangi kadungan air dari dalam biji kopi HS yang semula 60$65 \%$ sampai menjadi $12 \%$. Pada kadar air ini, biji koi HS relatif aman untuk dikemas dalam karung dan disimpan di dalam gudang pada lingkungan tropika. Beberapa jenis mesin pengering yang dapat diproduksi adalah dryer kapasitas $750 \mathrm{~kg} / \mathrm{b}$ atch dilengkapi dengan blower yang digerakkan oleh motor diesel 6-7 PK, kapasitas 1,5 ton/batch dilengkapi dengan blower yang digerakkan oleh motor diesel 6-7 PK, kapasitas 2,5 ton/batch dilengkapi dengan kipas aksial/blower yang digerakkan oleh motor diesel 7-8 PK, dan kapasitas 4 ton/batch dilengkapi dengan 3 kipas aksial yang digerakkan oleh motor diesel 7-8 PK atau motor listrik 7,5 PK, 3 phase (Puslit Kopi dan Kakao, 2013).

Beberapa mesin pengupasan digunakan untuk memisahkan biji kopi dengan kulit tanduk untuk mendapatkan biji kopi beras, mesin sangrai (roaster), mesin penggiling (grinder) untuk memperoleh butiran kopi bubuk dengan kehalusan tertentu, dan mesin pengemas telah diproduksi merupakan upaya untuk mempertahankan aroma dan cita rasa kopi bubuk selama transportasi dan distribusi ke konsumen dan selam dijajakan di toko atau di pasar atau selama disimpan oleh pemakai telah di produksi oleh Puslit Kopi dan Kakao di Jember.

\section{Analisis Finansial}

Dari hasil analisis kelayakan pabrik secara finansial selama 15 tahun, pendirian pabrik kopi tidak layak diusahakan. Beberapa kriteria kelayakan yang digunakan antara lain adalah Gross $B / C$, IRR, dan $N P V$ tidak layak. Gross $B / C=0,92$, Nilai IRR dibawah tingkat suku bunga (6\%/tahun), nilai NPV masih negatif. Asumsi dalam analisis kelayakan antara lain tingkat suku bunga deposito 1 tahun sekitar $6 \%$. 


\section{SIMPULAN}

Beberapa kesimpulan yang dapat ditarik dari penelitian ini adalah: 1) Dari beberapa jenis produk kopi dari dua kabupaten, kemungkinan peluang komersialisasi adalah kopi luwak (Paradoxurus hermaphrodites); 2) Beberapa jenis produk kopi dari proses industri (home industry) dari Kabupaten Sambas dan Kabupaten Pontianak belum memiliki keunggulan spesifik baik dari cita rasa dan aroma sehingga tidak terlihat peluang komersialisasinya; dan 3) Industri kopi di dua kabupaten, yaitu Sambas dan Kabupaen Pontianak tidak layak untuk dilaksanakan karena alasan ketersediaan bahan baku dan analisis finansial. Bahan baku di petani, produksinya selalu menurun dan tidak diminati petani untuk berproduksi dan kalah bersaing dengan komoditas perkebunan lain yaitu karet, kelapa sawit, dan berberapa jenis tanaman lain.

\section{Saran}

Beberapa saran dan rekomendasi yang dapat diberikan untuk Pemerintah Daerah dan masyarakat adalah 1) Budidaya kopi dan produk kopi luwak liar (Paradoxurus hermaphrodites) dari Kabupaten Sambas perlu diperhatikan dan dibina intensif oleh Pemerintah Daerah setempat, agar memiliki peluang komersialisasi yang kompetitif; dan 2) Sebaiknya Pemerintah Daerah membina kembali teknik budidaya dan manajemen usaha tani kopi, terutama pada daerah penghasil kopi luwak agar dapat menjadi tumpuan pendapatan masyarakat.

\section{DAFTAR PUSTAKA}

Asri, Ika Wahyu Yuni., 2010, Analisis Usaha Industri Emping Melinjo Skala Rumah Tangga Di Kabupaten Magetan, Fakultas Pertanian, Universitas Sebelas Maret, Surakarta.

Cahyana, Agus., 2008, Studi Pengembangan Desain Kerajinan Anyaman Pandan Sentra Industri Kecil Rajapaloh Kabupaten Tasikmalaya, Program Studi Seni Rupa Murni, Fakultas Seni Rupa dan Desain, Universitas Kristen Maranatha, Bandung.

Karo, H.S.A., 2009, Analisis UsahaTani Kopi di Kecamatan Simpang Empat Kabupaten Karo, skripsi, Departemen Agribisnis, F Pertanian Unive. Sumatera Utara, Medan.

Mulato, S., S. Widyotomo dan E. Suharyanto, 2010, Teknologi Proses dan Pengolahan Produk Primer dan Sekunder Kopi, Pusat Penelitian Kopi dan Kakao, Jember.

Mulato, S dan E. Suharyanto, 2011, Post Harvest Coffee Processing in Indonesia - An Introduction to Good Manufacturing Practice, Indonesian Coffee and Cocoa Research Institute, Jember.

Soraya, Putri., 2011, Studi Industri Kerajinan Serat Agel di Desa Salamrejo, Kecamatan Sentolo Kabupaten Kulon Progo, Program Studi Ilmu Sosial dan Ekonomi, Universitas Negeri Yogyakarta.
Surat Keputusan Gubernur Provinsi Kalimantan Barat Nomor 505 tahun 2002 tentang Komoditi Unggulan Daerah Kalimantan Barat. 
